\title{
Activation of an Effective Immune Response after Yellow Fever Vaccination Is Associated with the Genetic Background and Early Response of IFN- $\gamma$ and CLEC5A
}

\author{
Tamiris Azamor 1,2, Andréa Marques Vieira da Silva ${ }^{1}$, Juliana Gil Melgaço ${ }^{1} \mathbb{D}$, Ana Paula dos Santos ${ }^{1}$, \\ Caroline Xavier-Carvalho ${ }^{2}$, Lucia Elena Alvarado-Arnez ${ }^{3}$, Leonardo Ribeiro Batista-Silva ${ }^{4}$, \\ Denise Cristina de Souza Matos ${ }^{1}$ (D) Camilla Bayma ${ }^{1}$, Sotiris Missailidis ${ }^{1}$, Ana Paula Dinis Ano Bom ${ }^{1}$, \\ Milton Ozorio Moraes ${ }^{2}$ and Patrícia Cristina da Costa Neves ${ }^{1, * \mathbb{D}}$
}

\section{check for} updates

Citation: Azamor, T.; da Silva, A.M.V.; Melgaço, J.G.; dos Santos, A.P.; Xavier-Carvalho, C.; Alvarado-Arnez, L.E.; Batista-Silva, L.R.; de Souza Matos, D.C.; Bayma, C.; Missailidis, S.; et al. Activation of an Effective Immune Response after Yellow Fever Vaccination Is Associated with the Genetic Background and Early Response of IFN- $\gamma$ and CLEC5A. Viruses 2021, 13, 96. https://doi.org/10.3390/ v13010096

Academic Editors: Ashley L. St. John and Abhay P. S. Rathore

Received: 15 December 2020

Accepted: 8 January 2021

Published: 12 January 2021

Publisher's Note: MDPI stays neutral with regard to jurisdictional clai$\mathrm{ms}$ in published maps and institutional affiliations.

Copyright: () 2021 by the authors. Licensee MDPI, Basel, Switzerland. This article is an open access article distributed under the terms and conditions of the Creative Commons Attribution (CC BY) license (https:// creativecommons.org/licenses/by/ $4.0 /)$.
1 Bio-Manguinhos/Fundação Oswaldo Cruz, Rio de Janeiro 21040-900, Brazil; tamiris.azamor@bio.fiocruz.br (T.A.); amarques@bio.fiocruz.br (A.M.V.d.S.); juliana.melgaco@bio.fiocruz.br (J.G.M.); apaula@bio.fiocruz.br (A.P.d.S.); dmatos@bio.fiocruz.br (D.C.d.S.M.); camilla.bayma@bio.fiocruz.br (C.B.); sotiris.missailidis@bio.fiocruz.br (S.M.); adinis@bio.fiocruz.br (A.P.D.A.B.)

2 Instituto Oswaldo Cruz, Fundação Oswaldo Cruz, Rio de Janeiro 21040-900, Brazil; caroline_xc@yahoo.com.br (C.X.-C.); milton.moraes@fiocruz.br (M.O.M.)

3 National Research Coordination, Universidad Privada Franz Tamayo, Cochabamba 4780, Bolivia; lucia.alvarado@unifranz.edu.bo

4 Molecular Carcinogenesis Program-Research Coordination, Instituto Nacional do Câncer, Rio de Janeiro 20231-050, Brazil; leoribio@hotmail.com

* Correspondence: pcristina@bio.fiocruz.br; Tel.: +55-21-3882-7174

\begin{abstract}
The yellow fever vaccine (YF17DD) is highly effective with a single injection conferring protection for at least 10 years. The YF17DD induces polyvalent responses, with a TH1/TH2 CD4 ${ }^{+}$ profile, robust $\mathrm{T} \mathrm{CD}^{+}$responses, and synthesis of interferon-gamma (IFN- $\gamma$ ), culminating in high titers of neutralizing antibodies. Furthermore, C-type lectin domain containing 5A (CLEC5A) has been implicated in innate outcomes in other flaviviral infections. Here, we conducted a followup study in volunteers immunized with YF17DD, investigating the humoral response, cellular phenotypes, gene expression, and single nucleotide polymorphisms (SNPs) of IFNG and CLEC5A, to clarify the role of these factors in early response after vaccination. Activation of CLEC5A ${ }^{+}$ monocytes occurred five days after vaccination (DAV). Following, seven DAV data showed activation of $\mathrm{CD}^{+}$and $\mathrm{CD}^{+} \mathrm{T}$ cells together with early positive correlations between type II IFN and genes of innate antiviral response (STAT1, STAT2, IRF7, IRF9, OAS1, and RNASEL) as well as antibody levels. Furthermore, individuals with genotypes rs2430561 AT/AA, rs2069718 AG/AA (IFNG), and rs13237944 AC/AA (CLEC5A), exhibited higher expression of IFNG and CLEC5A, respectively. Together, we demonstrated that early IFN- $\gamma$ and CLEC5A responses, associated with rs2430561, rs2069718, and rs13237944 genotypes, may be key mechanisms in the long-lasting immunity elicited by YF17DD.
\end{abstract}

Keywords: yellow fever vaccine; interferon gamma; CLEC5A

\section{Introduction}

Yellow fever (YF) is a potentially fatal mosquito-borne disease caused by the neurovirulent and viscerotropic YF virus (YFV), from the genus flavivirus, family Flaviviridae. The mainstay of YF control involves control of the mosquito vectors Aedes Albopictus and Aedes aegypti, and vaccination [1]. The attenuated YF vaccine was developed in 1937 by Theiler and Smith through serial passages of the YFV wild-type Asibi strain in mice and chick minced embryo culture, generating the non-neurovirulent strain 17D which protected monkeys from challenge with a virulent strain of the virus with production of neutralizing 
antibodies [2]. After independent subcultures in chick embryo tissue, it was generated the strains of 17DD (YF17DD) used as a vaccine in South America, and 17D-204, used in the rest of the world $[3,4]$. Genome sequencing studies revealed mutations in non-coding regions, and amino acid differences in structural and non-structural proteins, including non-conservative variations in E299, E305, E331 and E380 within ectodomain III of envelope protein, the cell binding region [5-8]. Further, it was shown that YF vaccines present much lower quasispecies diversity, when compared with virulent strains $[9,10]$. Thence, the YF vaccine has been considered a gold standard vaccine, with an excellent efficacy and safety record, in that a single full dose is sufficient to confer sustained immunity and potentially life-long protection against YFV [11-13]. Clinical trials using one-fifth fractionated dose revealed that $17 \mathrm{D}$ confers protection for at least 10 years $[14,15]$. Despite its great efficacy, the cellular and molecular mechanisms by which the vaccine virus induces such protection are not yet fully elucidated [4].

The attenuated YFV is injected subcutaneously, mimetizing the natural route of entrance by mosquito bites, where the virus infects and activates human dendritic cells (DCs). As a response, the activated DCs express type I and III interferons and different pattern recognition receptors (toll-like receptors-2,7,8 and 9), and migrate to the lymph nodes, presenting virus antigens to a diverse repertoire of T cells [16-18]. Hence, the early events after YF vaccination consist of (i) a complex modulation of innate immune cytokines, (ii) a polyvalent cellular response, with a mixed proinflammatory $\mathrm{TH} 1 /$ regulatory $\mathrm{TH} 2 \mathrm{CD}^{+}$ cell profile, which results in a robust $\mathrm{CD}^{+} \mathrm{T}$ cell response, and a complex modulation of innate immune cytokines, culminating with (iii) production of neutralizing antibodies, which are the primary correlate of protection [19]. In this way, early events following immunization have a key role in determining the strength and quality of the adaptive immune response that develops. It was demonstrated that the primary immunization with the vaccine results in early release of the type II interferon, interferon-gamma (IFN- $\gamma$ ), a cytokine which improved the acquired immune responses in mice, and the levels of neutralizing antibodies in humans [20,21]. A growing body of evidence indicates that the production of IFN- $\gamma$ is regulated by single nucleotide polymorphisms (SNPs) within the IFNG gene, which may influence host susceptibility to a large range of diseases including dengue [22-25].

YF vaccines are effective and safe in most cases; however, some adverse events (AEs) and a few rare serious adverse events (SAEs) have been reported [26]. SAEs may occur following vaccination even in individuals that produce high neutralizing antibody levels [27-29], leading to the hypothesis of inborn innate response failure [30]. Thus, a few genetic studies have been carried out in isolated patients, revealing diverse backgrounds associated with a SAE outcome. These included a premature stop codon in the gene encoding the IFN- $\alpha / \beta$ receptor $\alpha$ chain (IFNAR1) [28], and pathology-associated SNPs in CCR5, RANTES [31], OAS1 and OAS2 [32], which encode a chemokine receptor, a chemokine ligand, and $2^{\prime}-5^{\prime}$-oligoadenylate synthetase 1 and 2, respectively. However, to date, there are no studies associating the genetic background with an effective response after YF vaccination.

The C-type lectin domain containing 5A (CLEC5A) is an immune receptor abundantly expressed in myeloid lineages, which bind a variety of bacterial and viral pathogens eliciting proinflammatory responses [33]. The role of CLEC5A has been demonstrated for several viral infections, such as those caused by other flaviviruses, Zika, Japanese encephalitis, and dengue, as well as influenza [33-36]. Both human and mouse CLEC5A have been reported to bind to the dengue virus, and this receptor has already been related to severe dengue fever [37]. CLEC5A activation by flaviviruses and influenza virus induces phosphorylation of DNAX adaptor protein 12 (DAP12), triggering an inflammatory response characterized by production of IFNs, proinflammatory cytokines, and neutrophils extracellular traps (NETs) [37,38]. Blockade of CLEC5A with monoclonal antibodies attenuates inflammatory reactions, without downregulating IFN production, thereby protecting the host from virus-induced inflammatory reactions [39]. 
Moreover, the relationship between certain CLEC5A genetic variants and the expression levels of CLEC5A has been indicated in previous clinical studies [39]. Interestingly, CLEC5A SNPs have already been associated with the disease outcome for dengue [40].

Herein, we investigated the early expression of genes related to the innate antiviral response, the cellular immune phenotypes and the humoral response after immunization with the YF vaccine (YF17DD of Brazil). Moreover, we genotyped SNPs of the IFNG and CLEC5A genes in volunteers immunized with YF17DD and associated them to an effective humoral and early innate response, confirming the role of IFN- $\gamma$ as a hub in YF vaccine protection and introducing CLEC5A as a new player in the YF vaccine immunologic response. Therefore, this study contributes to the understanding of the genotypic and phenotypic mechanisms associated with an effective immune response after YF vaccination.

\section{Materials and Methods}

\subsection{Study Group and Blood Samples}

Thirty-eight healthy volunteers, 23 women and 15 men, between 18 and 55 years old, were included in this study. In our sample, fifteen volunteers (11 woman and 4 men, mean $=33$ year-old) presented no history of YF vaccination and twenty-three (12 woman and 11 men, mean $=36$ years old) presented one previous YF17DD vaccination. All individuals were subcutaneously injected with a single $0.5 \mathrm{~mL}$ dose of the 17DD vaccine (Lot 007VFA010Z) as recommended by the manufacturer (Bio-Manguinhos, FIOCRUZ, Rio de Janeiro, Brazil). The volunteers were advised to report any clinical symptoms and adverse events after vaccination, but none were reported. The blood was collected before vaccination (day 0 ) and 3, 4, 5, 7, 10, and 60 days after vaccination (DAV). The study was conducted in accordance with fundamental ethical principles of the Declaration of Helsinki [41] and the Brazilian National Health Council on research involving human beings [42]. The study protocol was approved by the Research Ethics Committee of the National School of Public Health FIOCRUZ (protocol 145/01) and all volunteers gave their informed written consent before vaccination.

\subsection{Purification and Cryopreservation of Human Peripheral Blood Mononuclear Cells (PMBCs) and Sera}

PBMCs were obtained from $30 \mathrm{~mL}$ of heparinized venous blood. Blood samples were diluted 1:1 with RPMI 1640 medium (Sigma, St. Louis, MO, USA) and PBMCs were separated by performing a Histopaque ${ }^{\mathrm{TM}}$ gradient $(\mathrm{d}=1077 \mathrm{~g} / \mathrm{mL}$, Sigma-Aldrich, San Luis, MO, USA) following manufacturer's recommendations. The viability of the PBMCs was greater than 95\%, as assessed by Trypan blue (Invitrogen, Carlsbad, CA, USA) exclusion. Approximately $10^{7}$ PBMCs were resuspended in $1 \mathrm{~mL}$ freezing solution $[90 \%$ inactivated fetal bovine serum (FBS) (Gibco, Waltham, MA, USA) plus 10\% DMSO (Sigma)] and stored in liquid nitrogen until use. For sera samples, tubes containing $8 \mathrm{~mL}$ of venous blood and serum separator clot (Beckman-Coulter, Brea, CA, USA) were centrifuged at $400 \times g$ for $10 \mathrm{~min}$, and the supernatant was collected. Sera were stored at $-20^{\circ} \mathrm{C}$ until use.

\subsection{Quantification of Antibodies against the Yellow Fever Virus}

A new immunoenzymatic test, ViBI, was developed based on our previous work regarding the detection of neutralizing antibodies against tetanus and diphtheria toxins [43]. Plates were coated with $100 \mu \mathrm{L}$ of $1 \mu \mathrm{g} / \mathrm{mL}$ 2D12 monoclonal antibody (Bio-Rad, Hercules, CA, USA) in carbonate-bicarbonate buffer $\mathrm{pH} 9.6$ and incubated overnight at $4{ }^{\circ} \mathrm{C}$. The plates were washed 5 times with PBS/T washing buffer (PBS pH 7.4 with $0.05 \%$ Tween-20) and subsequently blocked with blocking/diluent solution (BDS) at $100 \mu \mathrm{L} /$ well [PBS/T, $0.05 \%$ bovine serum albumin (BSA), 3\% FBS and 5\% skimmed milk] for $1 \mathrm{~h}$ at $37^{\circ} \mathrm{C}$. Sera from immunized volunteers at $60 \mathrm{DAV}$ were diluted 1:10 in BDS to perform serial twofold dilutions. For the standard curve, twofold serial dilutions of the monkey antiyellow fever antibody serum (National Institute for Biological Standards and Control, UK), in BDS, ranging from 1000 to $0.008 \mathrm{mUI} / \mathrm{mL}$ plus $20 \mu \mathrm{g} / \mathrm{mL}$ were performed. A virus 
dose control (virus plus BDS only) and a blank control (BDS only) were also included. After $1 \mathrm{~h}$ at room temperature, rocking at $300 \mathrm{rpm}$, the plate was washed with PBS/T and incubated with $100 \mu \mathrm{L} /$ well of the 2D12 HRP-conjugated antibody diluted 1:800 in BDS and incubated for $1 \mathrm{~h}$ at $37^{\circ} \mathrm{C}$. After washing, $100 \mu \mathrm{L} /$ well of TMB plus (KemEnTec, Taastrup, Denmark) was added for $15 \mathrm{~min}$, followed by $100 \mu \mathrm{L} /$ well of $2 \mathrm{M} \mathrm{H}_{2} \mathrm{SO}_{4}$. Endpoint measurements were made at $450 \mathrm{~nm}$ using a VersaMax (Molecular Devices, San José, CA, USA). Calculations were performed with SoftMax Pro V5.4 (Molecular Devices, San José, CA, USA)and Microsoft Office 365Excel (Microsoft, Albuquerque, NM, USA).

\subsection{Immunolabeling for Flow Cytometry}

PBMCs from 0, 3, 5, and 7 DAV were thawed in RPMI medium (Thermo Fisher, Waltham, MA, USA) and $2 \times 10^{5}$ live cells were added to 96-well plates with $0.02 \mathrm{MOI}$ of YF17DD and maintained for $24 \mathrm{~h}$ with RPMI 1640 medium in a moist chamber at $37^{\circ} \mathrm{C}$ in $5 \% \mathrm{CO}_{2}$ atmosphere. For positive control, cells were incubated with $0.01 \mu \mathrm{g} /$ tube of phorbol 12-myristate 13-acetate (PMA) and $0.2 \mu \mathrm{g} /$ tube of ionomycin (Sigma-Aldrich). As a negative control, cells were incubated with RPMI 1640 medium (mock).

After incubation, cells were washed in PBS pH 7.2 supplemented with 1\% BSA and $0.1 \%$ sodium azide $\left(\mathrm{NaN}_{3}\right)$, then immunolabelled with the monoclonal antibodies antiCLEC5A-PE, and phenotypical markers of monocytic lineage (anti-CD14-APC, and antiCD16-FITC), $\mathrm{T}$ cells (anti-CD3-APC-Cy7), CD4 ${ }^{+} \mathrm{T}$ cells (anti-CD4-BV421), cellular activation (anti-HLA-DR-PE-Cy5), and apoptosis (anti-CD95-PE-Cy7) (Beckman-Coulter), for $30 \mathrm{~min}$ at $4{ }^{\circ} \mathrm{C}$, according to manufacturer's recommendation. Cytometric analyses were carried out in a BD LSR Fortessa ${ }^{\mathrm{TM}}$ Cell Analyzer (Becton Dickinson, Franklin Lakes, NJ, USA). For each sample, 10,000-20,000 events were acquired, and analyses were made with the FlowJo V10 software (FlowJo LLC, Ashland, OR, USA). The CD8 ${ }^{+}$T cells were characterized by excluding $\mathrm{CD}^{+}$from $\mathrm{CD}^{+}$cells. The gating strategy shown in Figure S1.

\subsection{DNA and RNA Extraction}

Genomic DNA extraction was performed from thawed cryopreserved PBMCs $\left(10^{7}\right.$ cells $)$ using the salting out methodology [28] and DNA was resuspended in TE buffer (5 mM Tris- $\mathrm{HCl}, 0.1 \mathrm{mM}$ EDTA). The RNA was extracted using TRIzol ${ }^{\mathrm{TM}}$ reagent (Thermo Fisher), followed by complementary DNA (cDNA) production from 250 ng of total RNA using the High-Capacity cDNA Reverse Transcription Kit (Thermo Fisher), both procedures according to the manufacturer's instructions. After isolation, the nucleic acids were quantified in a spectrophotometer (Nanodrop Technologies, Wilmington, DE, USA) and stored at $-20{ }^{\circ} \mathrm{C}$ until the time of use.

\subsection{Expression of Genes Related to an Antiviral Response}

The cDNA from each sample was used to quantify the mRNA of CLEC5A, DAP12, STAT1, STAT2, IRF7, IRF9, OAS1, RNASEL, IL6, IL12, CXCL10, NOS1, AIM2, IFI16, IFNGR1 and IFNG, as well as the reference genes GAPDH and RPL13 (genes and primer descriptions are given in Supplementary Table S1). To this end, Sybr Green master mix (Thermo Fisher) with $200 \mathrm{nM}$ of each primer (forward and reverse) and $10 \mathrm{ng}$ of each cDNA were used in a final reaction volume of $10 \mu \mathrm{L}$. The standard cycling conditions used were a pre-dwell for $10 \mathrm{~min}$ at $95^{\circ} \mathrm{C} ; 15 \mathrm{~s}$ at $95^{\circ} \mathrm{C}, 4 \mathrm{~min}$ at $60^{\circ} \mathrm{C}$, for 45 cycles. Gene expression was carried out using the ViiA ${ }^{\mathrm{TM}} 7$ Real-Time PCR System (Thermo Fisher). Data obtained were normalized to the average cycling threshold value of the reference gene RPL13, and then the difference in normalized cycling threshold values between 4,7 , and 10 DAV versus $0 \mathrm{DAV}$ was calculated, generating $2 \Delta \Delta \mathrm{Ct}$. Fold change $(2 \Delta \Delta \mathrm{Ct})$ was compared between the DAV times by a Kruskall-Wallis test with Dunn's post-test using the GraphPad Prism 5 software. 


\subsection{Genotyping and Genetic Analysis}

The DNAs of immunized volunteers were genotyped for SNPs using Taqman probes. For CLEC5A, two SNPs were genotyped: rs13237944, (+7569 C > A) and rs1285933 (C_9506735_10). As for IFNG, three SNPs were genotyped: rs2430561 (AH20TEB), rs2069718 (C_15799728_10), and rs1861493 (C_2683476_10) (SNPs descriptions are given in Supplementary Table S2). Genotyping was performed by allelic discrimination real-time PCR performed in a StepOne Plus instrument (Life Technologies, Carlsbad, CA, USA). Reactions containing 20-40 ng of DNA in a final volume of $20 \mu \mathrm{L}$ including $10 \mu \mathrm{L}$ of TaqMan Genotypin Master Mix (Life Technologies) and $0.5 \mu \mathrm{L}$ of each TaqMan probe were used in standard cycling conditions: a pre-dwell for $5 \mathrm{~min}$ at $95^{\circ} \mathrm{C} ; 15 \mathrm{~s}$ at $95^{\circ} \mathrm{C}, 30 \mathrm{~s}$ at $60^{\circ} \mathrm{C}$, for 40 cycles.

\section{Results}

\subsection{Activation of CLEC5A+ Monocytes and T Lymphocytes after YF17DD Vaccination}

After in vitro YF17DD stimulation of peripheral blood mononuclear cells collected from vaccinated volunteers, cellular activation was assessed through the expression of HLA$\mathrm{DR}^{+}$(Supplementary Figure S1). It was observed that the frequency of the subpopulation of activated monocytes not expressing CLEC5A did not exhibit statistically significant modulations over time (Figure 1A), unlike activated monocytes (CD3 ${ }^{-} \mathrm{CD} 95^{-} \mathrm{CD} 14^{+} \mathrm{HLA}-\mathrm{DR}^{+}$) expressing CLEC5A, which were significantly increased on the fifth day after vaccination (Figure 1B,C). These results suggest that CLEC5A is involved with monocyte activation after YF exposition and could act in the initial YF interaction with cells. Activated $\mathrm{CD} 4^{+} \mathrm{T}$ cells $\left(\mathrm{CD} 4^{+} \mathrm{HLA}-\mathrm{DR}{ }^{+}\right)$and $\mathrm{CD} 8^{+} \mathrm{T}$ cells $\left(\mathrm{CD} 8^{+} \mathrm{HLA}-\mathrm{DR}^{+}\right)$exhibited a gradual increase over time, with a peak at $7 \mathrm{DAV}$ (Figure 1C-E) and a positive correlation considering all times analyzed $(R=0.71 ; p=0.00001)$. In summary, the kinetics of YF17DD response involved a fist line response of CLEC5 $\mathrm{A}^{+}$activated monocytes at $5 \mathrm{DAV}$, followed by an activation of $\mathrm{CD}^{+}$and $\mathrm{CD} 8^{+}$cells $7 \mathrm{DAV}$ (Figure 1F).

\subsection{Expression of CLEC5A and Genes Related to Interferon Pathways Has a Positive Correlation} with YF17DD Vaccine Immunogenicity

Relative quantification of mRNA in the PBMCs of 17DD first-time vaccinated individuals $(n=15)$ demonstrated that genes related to the antiviral and inflammatory responses have an important role in the early events after YF vaccination. The expression of CLEC5A varied according to time, with high levels at 4 DAV and 10 DAV (Figure 2A), presenting a significant positive correlation with the anti-YF antibody production at $10 \mathrm{DAV}$ (Figure 2C). Furthermore, expression of CLEC5A did not show any correlation with DAP12 (Figure 2B,C), a gene that encodes the CLEC5A associated protein. At $7 \mathrm{DAV}$, there was a positive correlation of CLEC5A expression with the proinflammatory cytokine IL6 and the chemokine CXCL10, and genes related to the innate antiviral response (STAT1, IRF7, IRF9, OAS1, and RNASEL) (Figure 2B), suggesting that CLEC5A contributes to a proinflammatory and antiviral environment.

Interestingly, genes related to type II IFN pathway presented an early interaction with other antiviral genes, since times $7 \mathrm{DAV}$. At $7 \mathrm{DAV}$, an increase in the relative expression for the majority of analyzed genes was observed, which was significant for CXCL10 $(p<0.0001)$ (Figure 2A), a downstream chemokine of type I and II IFN pathways. Besides, at $7 \mathrm{DAV}$, expression of AIM2, IFNGR1 and IFNG presented a positive correlation with ViBI antibody levels (Figure 2B). Data also suggest at $10 \mathrm{DAV}$ an interaction network related with humoral response after YF vaccination: AIM2, IFI16, and STAT1, typical products of the IFN- $\gamma$ pathway, presented a positive correlation with CLEC5A, STAT2, IRF7, IRF9, OAS1, RNASEL and the antibody levels (Figure 2C). 
$A$

CD14+HLA-DR+

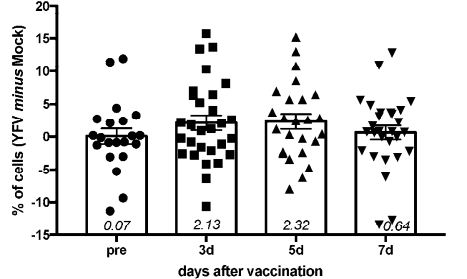

C Gated on CD3-CD95-CD14+HLADR+
$B$

CD14+HLA-DR+CLEC5A+

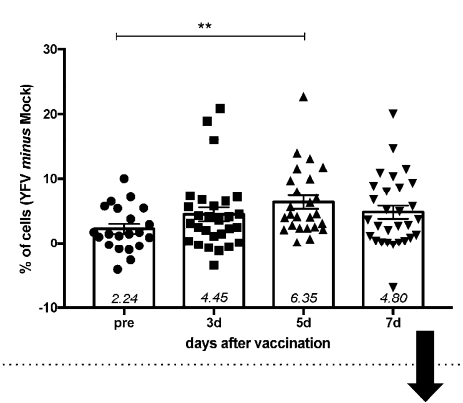

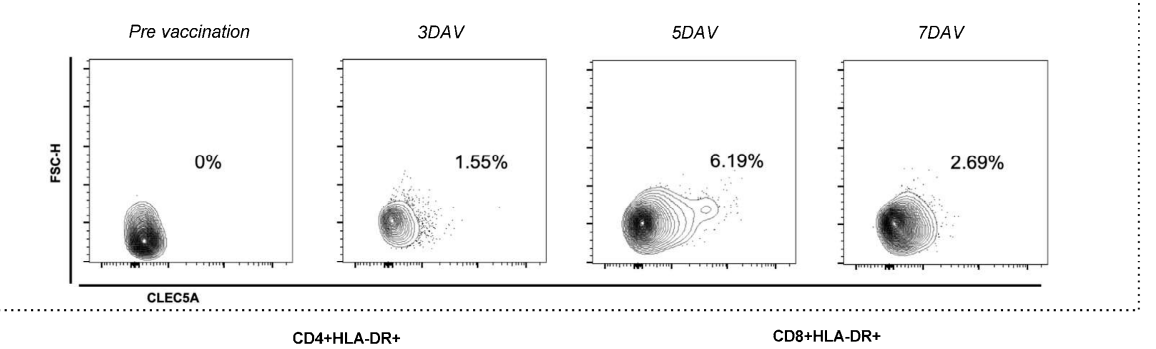

$D$

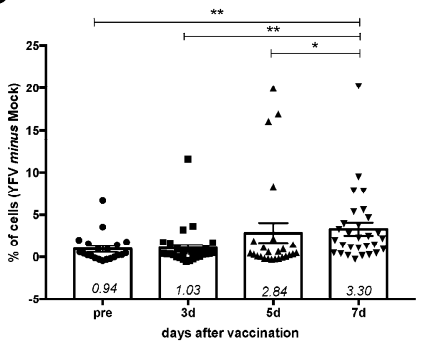

E

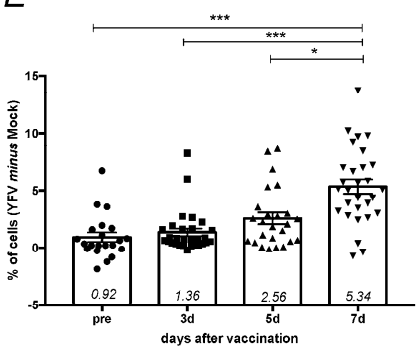

F

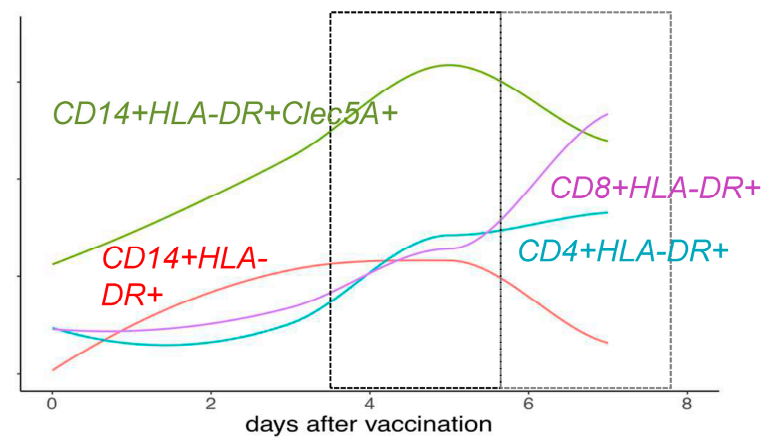

Figure 1. Phenotypes of monocytes and $\mathrm{T}$ lymphocytes during vaccination follow-up. Peripheral blood mononuclear cells (PBMCs) from vaccinated volunteers $(n=38,15$ first time vaccinated and $23 \mathrm{~s}$ time vaccinated) were stimulated for $24 \mathrm{~h}$ with YF17DD in vitro. Bar-graphs show the cell population frequencies of $(\mathbf{A})$ activated monocytes, represented as $\mathrm{CD}^{-} \mathrm{CD}^{-} 5^{-} \mathrm{CD} 14^{+} \mathrm{HLA}^{-} \mathrm{DR}^{+}$, and (B) activated monocytes expressing CLEC5A, represented as $\mathrm{CD}^{-}{ }^{-} \mathrm{CD} 95^{-} \mathrm{CD} 14^{+} \mathrm{HLA}-$ $\mathrm{DR}^{+} \mathrm{CLEC} 5 \mathrm{~A}^{+}$. Cell population frequencies were calculated by frequency in YF17DD stimulated experimental condition minus frequency in unstimulated (mock) experimental condition. (C) Cells from one subject are represented as a density plot (FlowJo Tree Star ${ }^{\circledR}$ ) showing the kinetics of CLEC5A expression on activated monocytes. (D) Activated CD4 ${ }^{+} \mathrm{T}$ cells are represented as $\mathrm{CD}^{+}{ }^{+} \mathrm{CD} 95^{-} \mathrm{CD} 4^{+} \mathrm{HLA}-\mathrm{DR}^{+}$. (E) Activated $\mathrm{CD} 8^{+} \mathrm{T}$ cells are represented as $\mathrm{CD} 3^{+} \mathrm{CD} 95^{-} \mathrm{CD} 4^{-} \mathrm{HLA}-\mathrm{DR}{ }^{+}$. Cell population frequencies were compared between time points using Kruskal-Wallis with Dunns post-test, with significant $p$ value represented as ${ }^{*} p<0.05,{ }^{* *} p<0.01,{ }^{* * *} p<0.001$. Each point corresponds to one individual analyzed, with median and standard error of groups. (F) Graphic representation of cellular phenotypes during vaccination follow-up. Lines

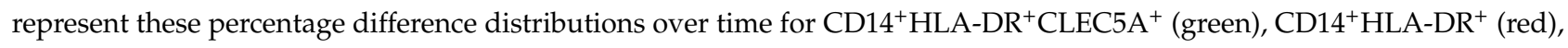
CD8 ${ }^{+} \mathrm{HLA}^{-\mathrm{DR}^{+}}$(purple), and CD4 ${ }^{+} \mathrm{HLA}^{-\mathrm{DR}^{+}}$(turquoise). 
$A$

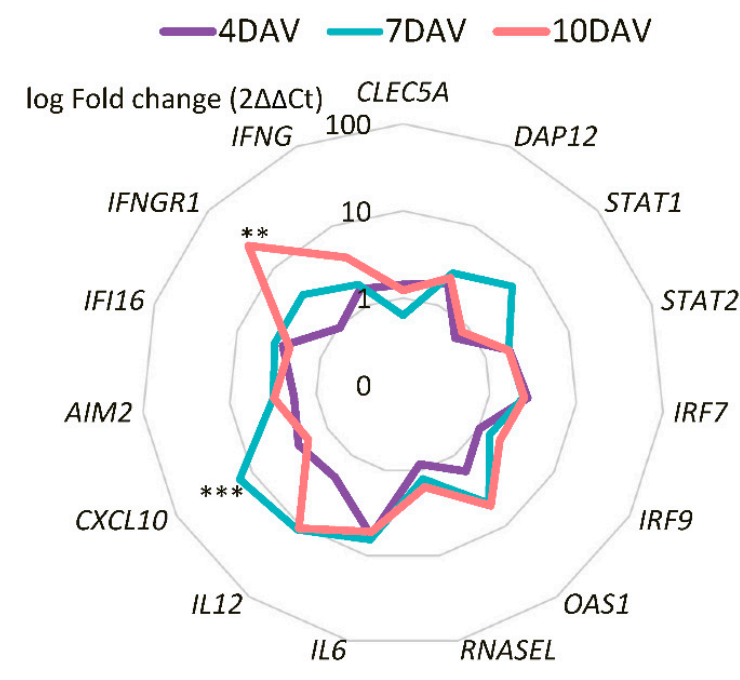

$B$

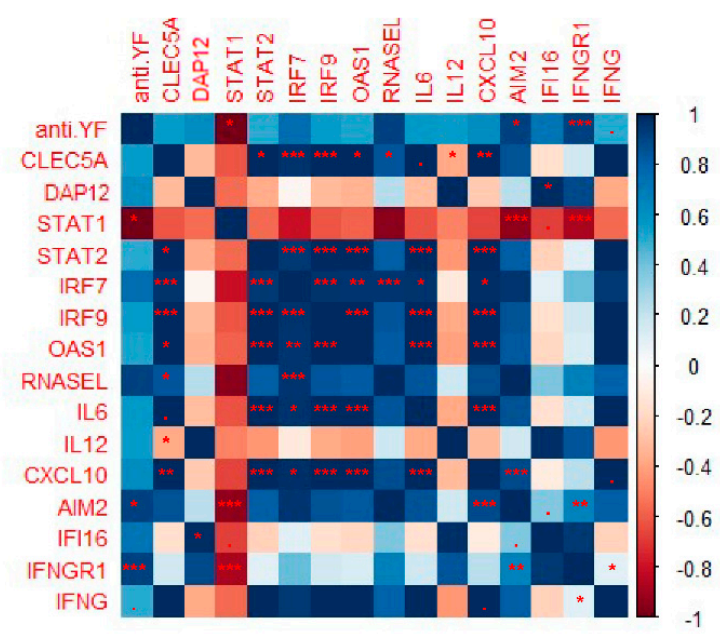

C

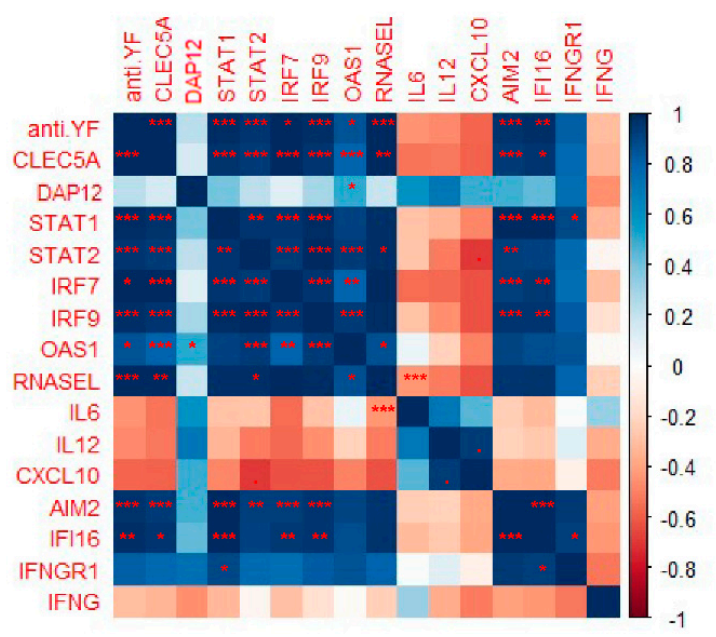

Figure 2. Gene expression profile of the early responses in first time YF17DD-vaccinated volunteers $(n=15)$. (A) Radar chart representing the average $\log 10$ fold change $(2 \Delta \Delta \mathrm{Ct})$ of each gene and day after vaccination (DAV). Mean $2 \Delta \Delta \mathrm{Ct}$ values of CLEC5A, DAP12, STAT1, STAT2, IRF7, IRF9, OAS1, RNASEL, IL6, IL12, CXCL10, NOS1, AIM2, IFI16, IFNGR1, and IFNG clustered by 4 DAV (red), 7 DAV (yellow), and 10 DAV (blue). Fold change $(2 \Delta \Delta \mathrm{Ct}$ ) was compared between DAV by Kruskall-Wallis test with Dunn's post-test using the GraphPad Prism 5 software. The heatmaps represent the correlation $\mathrm{R}$ values according to the $\mathrm{Z}$ score for $2 \Delta \Delta \mathrm{Ct}$ values of genes analyzed and anti-YF antibody production at (B) $7 \mathrm{DAV}$, and (C) 10 DAV. Spearman correlation and heatmaps by library "corrplor" from R-project. $p$ value is represented as $p<0.1$, ${ }^{*} p<0.05,{ }^{* *} p<0.01,{ }^{* * *} p<0.001$. 


\subsection{Polymorphism in CLEC5A and IFNG Genes Modulates the Immunologic Response to the YF17DD Vaccine}

In order to investigate whether SNPs in the CLEC5A and IFNG genes are related to the YF17DD vaccination immunologic response, the DNA of first-time vaccinated and revaccinated individuals $(n=38)$ were genotyped for three SNPs of the IFNG gene, rs2430561, rs2069718, and rs1861493, and two SNPs of the CLEC5A gene, rs13237944 and rs1285933. It was demonstrated that at 7 DAV a significant upregulation of CLEC5A expression occurred in individuals with genotypes AC/AA rs13237944 (Figure 3A), and of IFNG in individuals with genotypes AG/AA rs2430561 and AT/AA rs2069718, when compared with the the other possible genotypes (Figure 3B,C). Protein levels of CLEC5A in ex vivo-activated monocytes and circulating IFN- $\gamma$ did not demonstrate significant differences when clustering by genotypes (Supplementary Figure S2). Regarding anti-YF antibody production, data only showed a trend towards a higher antibody production at 60 DAV in genotypes marked by high expression of CLEC5A and IFNG (Figure 3D-F), although more sampling efforts are necessary to definitively associate the SNPs analyzed with the anti-YF antibody production after YF vaccination.
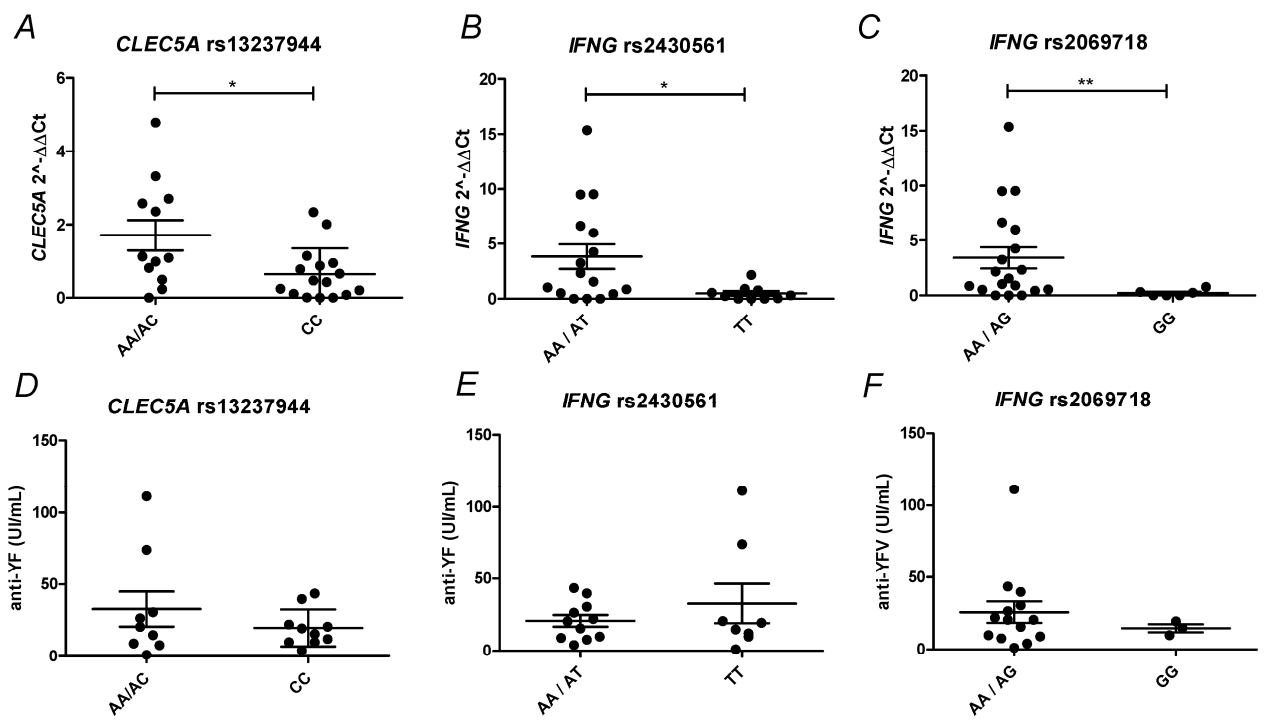

Figure 3. CLEC5A and IFNG SNPs associated with YF17DD immunologic responses. (A-C) Relative expression of CLEC5A and IFNG at 7 DAV according to SNP genotyping. The expression of CLEC5A and IFNG was stratified according to (A) rs13237944, (B) rs2430561, and (C) rs2069718 genotypes (n = 38). (D-F) Anti-YF antibody production according to SNP genotyping. Anti-YF antibody production at 60 DAV was stratified according to (A) rs13237944, (B) rs2430561, and (C) rs2069718 genotypes $(n=19)$. Each dot corresponds to one individual analyzed, with median and standard error of groups. Statistical analysis was determined using Mann-Whitney test. $p$ value is represented as ${ }^{*} p<0.05,{ }^{* *} p<0.01$. DAV: days after vaccination.

\section{Discussion}

The yellow fever vaccine has been used for more than 70 years on more than 400 million people, with a remarkable record of safety and efficacy. Despite this, there have been several recent outbreaks highlighting the continuous necessity of YF vaccination. Angola and the Democratic Republic of Congo experienced large outbreaks in 2015 and 2016, followed by Brazil and Nigeria in 2017 and 2018. Brazil has experienced increased YF outbreaks due to an ongoing YF epizootic transmission that has expanded from endemic zones to areas near the megacities of Rio de Janeiro and São Paulo [44]. In less than 18 months, 1833 confirmed cases and 578 deaths were recorded, most of them reported in the Rio de Janeiro-São Paulo axis [45]. Outbreaks are accompanied by massive vaccination schemes where rare SAE cases are eventually detected $[45,46]$. Furthermore, unvaccinated travelers 
visiting Brazilian endemic areas have acquired and died from YF with a higher frequency, compared with past decades, making YF vaccination a worldwide demand [47].

Here we investigated the integration between the innate and adaptive immune responses following YF17DD vaccination. Induction of innate virus-sensing genes and interferon production was observed, orchestrated by major transcription factors, including STAT2 and IRF7. Effector cells of the immune system, including early CD $8^{+} \mathrm{T}$ cell responses, a hallmark of YF17DD efficacy, were detected [4,48]. Herein, in the light of human genetic background, we demonstrated for the first time a possible role for the CLEC5A receptor after $\mathrm{YF}$ vaccination, and moreover, we focused on the importance of IFN- $\gamma$ as a key factor for vaccine immune response development.

First, it was demonstrated that a balanced proinflammatory environment is necessary for neutralizing antibody production in YF vaccination [49]. In this context, CLEC5A has been shown to be an important pattern recognition receptor for flavivirus and is involved with cytokine release from monocytic cells [37]. As shown before, the blockade of CLEC5 $\mathrm{A}^{-}$dengue virus interactions could attenuate inflammation and maintain host immunity so as to clear virus, in an IFN-independent manner [37]. Our results revealed that high gene expression and abundance of CLEC5A on the surface of activated monocytes are correlated with YF vaccine immunogenicity, as measured by antibodies at $60 \mathrm{DAV}$. Additionally, data demonstrated an early positive correlation between the expression of CLEC5A and the proinflammatory factors IL6 and CXCL10, already described as T cell activators [50-52]. Moreover, activated $\mathrm{CD}^{+}$and $\mathrm{CD} 8^{+} \mathrm{T}$ cells were also positive correlated with $\mathrm{CLEC}^{+}$monocytes. Based on these results and the role of CLEC5A described for other flaviviruses infections, we hypothesize that CLEC5A could act as a YFV receptor with a downstream activation cascade that stimulates proinflammatory cytokines secretion, helping the activation of T cells [33,36-38]. Nevertheless, we could not observe a correlation between levels of gene expression of CLEC5A and DAP12, the protein that is phosphorylated downstream CLEC5A activation [37,38]. It could be due to gene expression approach that does not cover phosphorylation activities, which probably is occurring in this case. At the genetic level, it was reported that individuals carrying the rs 1285933 CC genotype for CLEC5A present high levels of CLEC5A mRNA and milder dengue infections compared to those with other genotypes in the Brazilian population [53]. Despite a low sample size, according to what was observed for dengue, here we show that individuals with genotypes AA/CA for another SNP as eQTL (expression quantitative trait loci) for YFV (rs13237944), which is associated with high levels of CLEC5A mRNA.

Previous investigations on the cellular response following YF vaccination have reported the activation of $\mathrm{CD} 4^{+} \mathrm{T}$ cells by day seven, $\mathrm{CD} 19^{+} \mathrm{T}$ cells by day 15 , and $\mathrm{CD} 8^{+} \mathrm{T}$ cells by day 30 after vaccination $[30,54]$. ELISpot has been used to show that IFN- $\gamma$ was significantly increased on day 15 after YF17DD immunization [55]. Our data depicted events of $\mathrm{CD}^{+} \mathrm{T}$ cell activation as early as seven days after vaccination. We also covered the importance of innate network in response to YF17DD up to seven days after vaccination, presenting the early correlations between type II IFN genes and the transcription factors IRF7, IRF9, STAT1, and STAT2, as well as OAS1. Together, these data suggest that the IFN- $\gamma$ response produced by CD ${ }^{+}$cells may start seven days after YF17DD vaccination, evidencing its prolonged and crucial role for YF17DD immunogenicity, according to similar studies $[4,36]$. Another group has observed similar results in humans [21]. Markedly, our results corroborated this hypothesis, as expression of genes related to the IFN- $\gamma$ pathway (AIM2, IFI16, and STAT1) at 10 DAV displayed a high correlation with anti-YF antibody levels. Despite low sample size, individuals with the genotypes AT/AA of rs2430561 and AG/AA of rs2069718 showed greater IFNG expression levels, highlighting these eQTL loci as possible targets for future association studies on YF immunogenicity.

In conclusion, the present study showed that the early events elicited after YF17DD vaccination are, at least in part, associated with and controlled by human genetic background, as observed here at CLEC5A and IFNG. Nevertheless, it is likely that several other SNPs and environmental and biological factors also contribute to the complex immune 
response triggered after YF17DD vaccination, in a way that we cannot extrapolate that long-lasting immunity is due to host genetics. Moreover, we confirmed that the IFN- $\gamma$ pathway acts as a hub in YF17DD protection and as well we introduced CLEC5A as a new player during the YF response, at both the phenotypic and genotypic levels.

Supplementary Materials: The following are available online at https:/ /www.mdpi.com/1999-491 5/13/1/96/s1, Figure S1: Gating strategy for activated T lymphocytes and monocytes by flow cytometry, Figure S2: CLEC5A and IFN- $\gamma$ protein levels according SNPs analyzed, Table S1: Descriptions of genes, main immunological roles and primer pairs, Table S2: Selected SNPs descriptions.

Author Contributions: T.A., A.M.V.d.S., L.E.A.-A., M.O.M., and P.C.d.C.N. designed experiments and reviewed data. T.A., A.M.V.d.S., C.X.-C., J.G.M., and C.B. performed experiments. T.A., J.G.M., and L.E.A.-A. performed statistical analyzes, P.C.d.C.N. and A.P.d.S. collected samples and provided clinical information. L.R.B.-S. and D.M. contributed to data understanding. T.A., A.M.V.d.S., J.G.M., A.P.D.A.B., and P.C.d.C.N. wrote the manuscript. S.M., A.P.D.A.B., P.C.d.C.N., and M.O.M. revised the manuscript. D.C.d.S.M. Funding acquisition. All authors have read and agreed to the published version of the manuscript.

Funding: This research was funded by Fundação Oswaldo Cruz, Conselho Nacional de Desenvolvimento Científico e Tecnológico (CNPq), Instituto de Tecnologia em Imunobiológicos Bio-Manguinhos, Programa InovaBio, grant BIO-004-FIO-17-2-20 to Andréa Marques Vieira da Silva, and Fundação Carlos Chagas Filho de Amparo à Pesquisa do Estado do Rio de Janeiro (FAPERJ-Programa de Auxílio ao Pesquisador Recém-contratado), grant 010.002596/2019; 211.369/2019 to Juliana Gil Melgaço.

Institutional Review Board Statement: The study was conducted according to the guidelines of the Declaration of Helsinki, and approved by the Research Ethics Committee of the National School of Public Health FIOCRUZ (protocol 145/01).

Informed Consent Statement: Informed consent was obtained from all subjects involved in the study.

Data Availability Statement: Data available on request due to restrictions eg privacy or ethical. The data presented in this study are available on request from the corresponding author. The data are not publicly available due to ethical reasons.

Acknowledgments: We would like to thank the staff at the Laboratório de Tecnologia Imunológica (Bio-Manguinhos, FIOCRUZ) and Laboratório de Hanseníase (Instituto Oswaldo Cruz, FIOCRUZ) for technical collaboration.

Conflicts of Interest: The authors declare no conflict of interest.

\section{References}

1. Chen, L.H.; Wilson, M.E. Yellow Fever Control: Current Epidemiology and Vaccination Strategies. Trop. Dis. Travel Med. Vaccines 2020, 6, 1. [CrossRef] [PubMed]

2. Theiler, M.; Smith, H.H. The use of yellow fever virus modified by in vitro cultivation for human immunization. J. Exp. Med. 1937, 65, 787-800. [CrossRef] [PubMed]

3. Monath, T.P. Yellow Fever Vaccine. Expert Rev. Vaccines 2005, 4, 553-574. [CrossRef] [PubMed]

4. Pulendran, B. Learning Immunology from the Yellow Fever Vaccine: Innate Immunity to Systems Vaccinology. Nat. Rev. Immunol. 2009, 9, 741-747. [CrossRef]

5. $\quad$ Rice, C.; Lenches, E.; Shin, S.; Sheets, R.; Strauss, J. Nucleotide Sequence of Yellow Fever Virus: Implications for Flavivirus Gene Expression and Evolution. Science 1985, 229, 726-733. [CrossRef]

6. Ryman, K.D.; Ledger, T.N.; Campbell, G.A.; Watowich, S.J.; Barrett, A.D.T. Mutation in a 17D-204 Vaccine Substrain-Specific Envelope Protein Epitope Alters the Pathogenesis of Yellow Fever Virus in Mice. Virology 1998, 244, 59-65. [CrossRef]

7. Duarte dos Santos, C.N.; Post, P.R.; Carvalho, R.; Ferreira, I.I.; Rice, C.M.; Galler, R. Complete Nucleotide Sequence of Yellow Fever Virus Vaccine Strains 17DD and 17D-213. Virus Res. 1995, 35, 35-41. [CrossRef]

8. Hahn, C.S.; Dalrymple, J.M.; Strauss, J.H.; Rice, C.M. Comparison of the Virulent Asibi Strain of Yellow Fever Virus with the 17D Vaccine Strain Derived from It. Proc. Natl. Acad. Sci. USA 1987, 84, 2019-2023. [CrossRef]

9. Beck, A.; Tesh, R.B.; Wood, T.G.; Widen, S.G.; Ryman, K.D.; Barrett, A.D.T. Comparison of the Live Attenuated Yellow Fever Vaccine 17D-204 Strain to Its Virulent Parental Strain Asibi by Deep Sequencing. J. Infect. Dis. 2014, 209, 334-344. [CrossRef]

10. Beck, A.S.; Wood, T.G.; Widen, S.G.; Thompson, J.K.; Barrett, A.D.T. Analysis By Deep Sequencing of Discontinued Neurotropic Yellow Fever Vaccine Strains. Sci. Rep. 2018, 8, 13408. [CrossRef] 
11. Wieten, R.W.; Jonker, E.F.F.; van Leeuwen, E.M.M.; Remmerswaal, E.B.M.; ten Berge, I.J.M.; de Visser, A.W.; van Genderen, P.J.J.; Goorhuis, A.; Visser, L.G.; Grobusch, M.P.; et al. A Single 17D Yellow Fever Vaccination Provides Lifelong Immunity; Characterization of Yellow-Fever-Specific Neutralizing Antibody and T-Cell Responses after Vaccination. PLoS ONE 2016, 11, e0149871. [CrossRef] [PubMed]

12. Poland, J.D.; Calisher, C.H.; Monath, T.P.; Downs, W.G.; Murphy, K. Persistence of Neutralizing Antibody 30-35 Years after Immunization with 17D Yellow Fever Vaccine. Bull. World Health Organ. 1981, 59, 895-900. [PubMed]

13. Gotuzzo, E.; Yactayo, S.; Córdova, E. Efficacy and Duration of Immunity after Yellow Fever Vaccination: Systematic Review on the Need for a Booster Every 10 Years. Am. J. Trop. Med. Hyg. 2013, 89, 434-444. [CrossRef] [PubMed]

14. Roukens, A.H.E.; van Halem, K.; de Visser, A.W.; Visser, L.G. Long-Term Protection After Fractional-Dose Yellow Fever Vaccination: Follow-up Study of a Randomized, Controlled, Noninferiority Trial. Ann. Intern. Med. 2018, 169, 761. [CrossRef] [PubMed]

15. De Menezes Martins, R.; Maria de Lourdes, S.M.; de Lima, S.M.B.; de Noronha, T.G.; Xavier, J.R.; Camacho, L.A.B.; de Albuquerque, E.M.; Farias, R.H.G.; da Matta de Castro, T.; Homma, A. Duration of Post-Vaccination Immunity to Yellow Fever in Volunteers Eight Years after a Dose-Response Study. Vaccine 2018, 36, 4112-4117. [CrossRef]

16. Barba-Spaeth, G.; Longman, R.S.; Albert, M.L.; Rice, C.M. Live Attenuated Yellow Fever 17D Infects Human DCs and Allows for Presentation of Endogenous and Recombinant T Cell Epitopes. J. Exp. Med. 2005, 202, 1179-1184. [CrossRef]

17. Querec, T.; Bennouna, S.; Alkan, S.; Laouar, Y.; Gorden, K.; Flavell, R.; Akira, S.; Ahmed, R.; Pulendran, B. Yellow Fever Vaccine YF-17D Activates Multiple Dendritic Cell Subsets via TLR2, 7, 8, and 9 to Stimulate Polyvalent Immunity. J. Exp. Med. 2006, 203, 413-424. [CrossRef]

18. Douam, F.; Soto Albrecht, Y.E.; Hrebikova, G.; Sadimin, E.; Davidson, C.; Kotenko, S.V.; Ploss, A. Type III Interferon-Mediated Signaling is Critical for Controlling Live Attenuated Yellow Fever Virus Infection in vivo. mBio 2017, 8, e00819-17. [CrossRef]

19. Watson, A.; Klimstra, W. T Cell-Mediated Immunity towards Yellow Fever Virus and Useful Animal Models. Viruses 2017, 9, 77. [CrossRef]

20. Neves, P.C.C.; Santos, J.R.; Tubarão, L.N.; Bonaldo, M.C.; Galler, R. Early IFN-Gamma Production after YF 17D Vaccine Virus Immunization in Mice and Its Association with Adaptive Immune Responses. PLoS ONE 2013, 8, e81953. [CrossRef]

21. Kohler, S.; Bethke, N.; Böthe, M.; Sommerick, S.; Frentsch, M.; Romagnani, C.; Niedrig, M.; Thiel, A. The Early Cellular Signatures of Protective Immunity Induced by Live Viral Vaccination: Immunity to Infection. Eur. J. Immunol. 2012, 42, 2363-2373. [CrossRef] [PubMed]

22. Avendaño-Tamayo, E.; Campo, O.; Chacón-Duque, J.C.; Ramírez, R.; Rojas, W.; Agudelo-Flórez, P.; Bedoya, G.; Restrepo, B.N. Variants in the TNFA, IL6 and IFNG Genes Are Associated with the Dengue Severity in a Sample from Colombian Population. Biomedica 2017, 37, 486. [CrossRef] [PubMed]

23. Zhuo, Y.; Yang, Y.; Zhang, M.; Xu, Y.; Chen, Z.; Mu, L.; Tang, X.; Zhong, Z.; Chen, J.; Zhou, L. Single Nucleotide Polymorphisms in IFN- $\gamma$ Signaling Pathway Associated with Risk of Hepatitis B Virus Infection in Chinese Children. Can. J. Infect. Dis. Med Microbiol. 2020, 2020, 1-8. [CrossRef] [PubMed]

24. Wu, S.; Wang, Y.; Zhang, M.; Wang, M.; He, J.-Q. Genetic Variants in IFNG and IFNGR1 and Tuberculosis Susceptibility. Cytokine 2019, 123, 154775. [CrossRef] [PubMed]

25. Silva, G.A.V.; Naveca, F.G.; Ramasawmy, R.; Boechat, A.L. Association between the IFNG +874A/T Gene Polymorphism and Leprosy Resistance: A Meta-Analysis. Cytokine 2014, 65, 130-133. [CrossRef] [PubMed]

26. Tomashek, K.M.; Challberg, M.; Nayak, S.U.; Schiltz, H.F. Disease Resurgence, Production Capability Issues and Safety Concerns in the Context of an Aging Population: Is There a Need for a New Yellow Fever Vaccine? Vaccines 2019, 7, 179. [CrossRef]

27. Doblas, A.; Domingo, C.; Bae, H.G.; Bohórquez, C.L.; de Ory, F.; Niedrig, M.; Mora, D.; Carrasco, F.J.; Tenorio, A. Yellow Fever Vaccine-Associated Viscerotropic Disease and Death in Spain. J. Clin. Virol. 2006, 36, 156-158. [CrossRef]

28. Hernandez, N.; Bucciol, G.; Moens, L.; Le Pen, J.; Shahrooei, M.; Goudouris, E.; Shirkani, A.; Changi-Ashtiani, M.; Rokni-Zadeh, H.; Sayar, E.H.; et al. Inherited IFNAR1 Deficiency in Otherwise Healthy Patients with Adverse Reaction to Measles and Yellow Fever Live Vaccines. J. Exp. Med. 2019, 216, 2057-2070. [CrossRef]

29. Volkov, L.; Grard, G.; Bollaert, P.-E.; Durand, G.A.; Cravoisy, A.; Conrad, M.; Nace, L.; Courte, G.; Marnai, R.; Leparc-Goffart, I.; et al. Viscerotropic Disease and Acute Uveitis Following Yellow Fever Vaccination: A Case Report. BMC Infect. Dis. 2020, $20,116$. [CrossRef]

30. Barrett, A.D.; Teuwen, D.E. Yellow Fever Vaccine-How Does It Work and Why Do Rare Cases of Serious Adverse Events Take Place? Curr. Opin. Immunol. 2009, 21, 308-313. [CrossRef]

31. Pulendran, B.; Miller, J.; Querec, T.D.; Akondy, R.; Moseley, N.; Laur, O.; Glidewell, J.; Monson, N.; Zhu, T.; Zhu, H.; et al. Case of Yellow Fever Vaccine-Associated Viscerotropic Disease with Prolonged Viremia, Robust Adaptive Immune Responses, and Polymorphisms in CCR5 and RANTES Genes. J. Infect. Dis. 2008, 198, 500-507. [CrossRef] [PubMed]

32. Belsher, J.L.; Gay, P.; Brinton, M.; DellaValla, J.; Ridenour, R.; Lanciotti, R.; Perelygin, A.; Zaki, S.; Paddock, C.; Querec, T.; et al. Fatal Multiorgan Failure Due to Yellow Fever Vaccine-Associated Viscerotropic Disease. Vaccine 2007, 25, 8480-8485. [CrossRef] [PubMed]

33. Sung, P.-S.; Hsieh, S.-L. CLEC2 and CLEC5A: Pathogenic Host Factors in Acute Viral Infections. Front. Immunol. 2019, 10, 2867. [CrossRef] [PubMed] 
34. Alagarasu, K.; Bachal, R.V.; Tillu, H.; Mulay, A.P.; Kakade, M.B.; Shah, P.S.; Cecilia, D. Association of Combinations of Interleukin10 and pro-Inflammatory Cytokine Gene Polymorphisms with Dengue Hemorrhagic Fever. Cytokine 2015, 74, 130-136. [CrossRef]

35. Yoshikawa, F.S.Y.; Pietrobon, A.J.; Branco, A.C.C.C.; Pereira, N.Z.; Oliveira, L.M.D.S.; Machado, C.M.; Duarte, A.J.D.S.; Sato, M.N. Zika Virus Infects Newborn Monocytes Without Triggering a Substantial Cytokine Response. J. Infect. Dis. 2019, $220,32-40$. [CrossRef]

36. Watson, A.A.; Lebedev, A.A.; Hall, B.A.; Fenton-May, A.E.; Vagin, A.A.; Dejnirattisai, W.; Felce, J.; Mongkolsapaya, J.; Palma, A.S.; Liu, Y.; et al. Structural Flexibility of the Macrophage Dengue Virus Receptor Clec5a: Implications for Ligand Binding and signaling. J. Biol. Chem. 2011, 286, 24208-24218. [CrossRef]

37. Chen, S.-T.; Lin, Y.-L.; Huang, M.-T.; Wu, M.-F.; Cheng, S.-C.; Lei, H.-Y.; Lee, C.-K.; Chiou, T.-W.; Wong, C.-H.; Hsieh, S.-L. CLEC5A Is Critical for Dengue-Virus-Induced Lethal Disease. Nature 2008, 453, 672-676. [CrossRef]

38. Chen, S.-T.; Liu, R.-S.; Wu, M.-F.; Lin, Y.-L.; Chen, S.-Y.; Tan, D.T.-W.; Chou, T.-Y.; Tsai, I.-S.; Li, L.; Hsieh, S.-L. CLEC5A Regulates Japanese Encephalitis Virus-Induced Neuroinflammation and Lethality. PLoS Pathog. 2012, 8, e1002655. [CrossRef]

39. Lectin in Host Defense Against Microbial Infections; Hsieh, S.-L. (Ed.) Advances in Experimental Medicine and Biology; Springer: Singapore, 2020; Volume 1204, ISBN 9789811515798.

40. Xavier-Carvalho, C.; Gibson, G.; Brasil, P.; Ferreira, R.X.; de Souza Santos, R.; Gonçalves Cruz, O.; de Oliveira, S.A.; de Sá Carvalho, M.; Pacheco, A.G.; Kubelka, C.F.; et al. Single Nucleotide Polymorphisms in Candidate Genes and Dengue Severity in Children: A Case-Control, Functional and Meta-Analysis Study. Infect. Genet. Evol. 2013, 20, 197-205. [CrossRef]

41. World Medical Association WMA Declaration of Helsinki-Ethical Principles for Medical Research Involving Human Subjects 2018. Available online: https:/ / www.wma.net/policies-post/wma-declaration-of-helsinki-ethical-principles-for-medicalresearch-involving-human-subjects / (accessed on 9 July 2018).

42. Ministério da Saúde, C.N.; de Resolução, S. No 466, de 12 de Dezembro de 2012 2012. Available online: https:/ /bvsms.saude.gov.

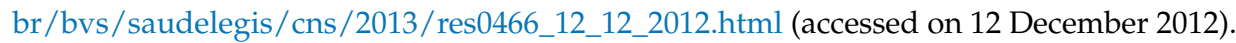

43. Matos, D.C.S.; Marcovistz, R.; Cabello, P.H.; Georgini, R.A.; Sakauchi, D.; Silva, L.L.D. Immunogenicity Test of Tetanus Component in Adsorbed Vaccines by Toxin Binding Inhibition Test. Memórias Inst. Oswaldo Cruz 2002, 97, 909-913. [CrossRef]

44. Laitinen, J.; Samarut, J.; Hölttä, E. A Nontoxic and Versatile Protein Salting-out Method for Isolation of DNA. BioTechniques 1994, 17, 316, 318, 320-322. [PubMed]

45. WHO Yellow Fever-Brazil 2019. Available online: https://www.who.int/csr/don/18-april-2019-yellow-fever-brazil/en/ (accessed on 18 April 2019).

46. Possas, C.; Lourenço-de-Oliveira, R.; Tauil, P.L.; Pinheiro, F.D.P.; Pissinatti, A.; Cunha, R.V.D.; Freire, M.; Martins, R.M.; Homma, A. Yellow Fever Outbreak in Brazil: The Puzzle of Rapid Viral Spread and Challenges for Immunisation. Memórias Inst. Oswaldo Cruz 2018, 113. [CrossRef] [PubMed]

47. Lucena, A.R.F.P.; Souza, L.R.D.O.; Percio, J.; Carvalho, S.M.D.; Romano, A.P.M.; Domingues, C.M.A.S. Fatores associados à gravidade dos eventos adversos pós-vacinação contra a febre amarela durante o maior surto da doença registrado no Brasil, 2016-2017. Epidemiol. Serviços Saúde 2020, 29. [CrossRef] [PubMed]

48. Hamer, D.H.; Angelo, K.; Caumes, E.; van Genderen, P.J.J.; Florescu, S.A.; Popescu, C.P.; Perret, C.; McBride, A.; Checkley, A.; Ryan, J.; et al. Fatal Yellow Fever in Travelers to Brazil, 2018. MMWR Morb. Mortal. Wkly. Rep. 2018, 67, 340-341. [CrossRef] [PubMed]

49. Santos, A.P.; Matos, D.C.S.; Bertho, A.L.; Mendonça, S.C.F.; Marcovistz, R. Detection of T H 1/T H 2 Cytokine Signatures in Yellow Fever 17DD First-Time Vaccinees through ELISpot Assay. Cytokine 2008, 42, 152-155. [CrossRef]

50. Silva, M.L.; Martins, M.A.; Espírito-Santo, L.R.; Campi-Azevedo, A.C.; Silveira-Lemos, D.; Ribeiro, J.G.L.; Homma, A.; Kroon, E.G.; Teixeira-Carvalho, A.; Elói-Santos, S.M.; et al. Characterization of Main Cytokine Sources from the Innate and Adaptive Immune Responses Following Primary 17DD Yellow Fever Vaccination in Adults. Vaccine 2011, 29, 583-592. [CrossRef]

51. Tanaka, T.; Narazaki, M.; Kishimoto, T. IL-6 in Inflammation, Immunity, and Disease. Cold Spring Harb. Perspect. Biol. 2014, 6, a016295. [CrossRef]

52. Liu, M.; Guo, S.; Hibbert, J.M.; Jain, V.; Singh, N.; Wilson, N.O.; Stiles, J.K. CXCL10/IP-10 in Infectious Diseases Pathogenesis and Potential Therapeutic Implications. Cytokine Growth Factor Rev. 2011, S1359610111000293. [CrossRef]

53. Xavier-Carvalho, C.; Cezar, R.D.S.; Freire, N.M.; de Vasconcelos, C.M.M.; Solorzano, V.E.F.; de Toledo-Pinto, T.G.; Fialho, L.G.; do Carmo, R.F.; Vasconcelos, L.R.S.; Cordeiro, M.T.; et al. Association of Rs1285933 Single Nucleotide Polymorphism in CLEC5A Gene with Dengue Severity and Its Functional Effects. Human Immunol. 2017, 78, 649-656. [CrossRef]

54. Gaucher, D.; Therrien, R.; Kettaf, N.; Angermann, B.R.; Boucher, G.; Filali-Mouhim, A.; Moser, J.M.; Mehta, R.S.; Drake, D.R.; Castro, E.; et al. Yellow Fever Vaccine Induces Integrated Multilineage and Polyfunctional Immune Responses. J. Exp. Med. 2008, 205, 3119-3131. [CrossRef]

55. Martins, M.Â.; Silva, M.L.; Marciano, A.P.V.; Peruhype-Magalhães, V.; Eloi-Santos, S.M.; Ribeiro, J.G.L.; Correa-Oliveira, R.; Homma, A.; Kroon, E.G.; Teixeira-Carvalho, A.; et al. Activation/Modulation of Adaptive Immunity Emerges Simultaneously after 17DD Yellow Fever First-Time Vaccination: Is This the Key to Prevent Severe Adverse Reactions Following Immunization?: Blood Lymphocytes in YF 17DD Vaccination. Clin. Exp. Immunol. 2007, 148, 90-100. [CrossRef] [PubMed] 